WMJ (Warmadewa Medical Journal), Vol. 5 No. 2 2020, Hal. 70-75

\title{
Noise Exposure Decreases the Number of Spermatozoa in Male Mice (Mus musculus L.) Even With Grape Seed Extract (Vitis vi- nifera L.) Administration
}

\author{
Ghestiara Pusphita Hannum Siregar ${ }^{1}$, Mila Citrawati ${ }^{2}$, Yudhi Nugraha ${ }^{3}$ \\ Faculty of Medicine, Universitas Pembangunan Nasional Veteran Jakarta \\ Jl. RS Fatmawati, Pondok Labu, Jakarta Selatan 12450 \\ *Corresponding author: Yudhi Nugraha \\ Email:ynugraha@upnvj.ac.id
}

\begin{abstract}
Excessive continuous noises exposure changes the male hormone system which leads to formation of oxidative stress and results in disrupt of semen quality. This condition can be reduced by the use of antioxidants. Grape seed is one of the antioxidants that contains phenol components that have Resveratrol compounds. This research aimed to observe the effect of noise exposure on the number of spermatozoa of male mice given grape seed extract. The method of the research was a post-test only control group design with research subjects of 30 male Mus musculus L. (Swiss Webster) mice divided into 5 groups: group A (treatment control) was not given noise exposure and grape seed extract, group B (negative control) was not given noise exposure and was given grape seed extract, groups $C, D, E$ (treatment group) were given noise exposure with sequential intensities of $65 \mathrm{~dB}, 85 \mathrm{~dB}, 105 \mathrm{~dB}$. The treatment was given for 33 days. The results showed that noise exposure with different intensities of $65 \mathrm{~dB}, 85 \mathrm{~dB}, 105 \mathrm{~dB}$ reduced the spermatozoa count of male Swiss Webster mice even with the administration of grape seed extract. One Way Anova test was used to analyze the data with p-value of 0.001. Conclusion: There were differences in spermatozoa count between the control group and the treatment group. Provision of noise exposure with a value above the threshold limit reduces the number of male Swiss Webster mice spermatozoa given with grape seed extract.
\end{abstract}

Keywords: Number of Spermatozoa, Grape Seed Extract, Noise exposure

Abstrak

[Pengaruh Paparan Kebisingan Terhadap Jumlah Spermatozoa Mencit Jantan (Mus musculus L) yang diberikan Ekstrak Biji Anggur (Vitis vinifera L.)]

Kebisingan yang melebihi nilai ambang batas dan dipaparkan secara terus menerus dapat berdampak pada perubahan sistem hormon laki-laki, terbentuknya stres oksidatif, dan gangguan jumlah spermatozoa. Kondisi tersebut dapat diperbaiki dengan pengunaan antioksidan. Biji anggur adalah salah satu antioksidan yang mengandung komponen fenol yang memiliki senyawa resveratrol. Penelitian ini bertujuan untuk melihat pengaruh paparan kebisingan terhadap jumlah spermatozoa mencit jantan yang diberikan ekstrak biji anggur. Penelitian ini menggunakan post test only control group, subjek penelitian ialah 30 mencit jantan galur Swiss Webster terbagi atas 5 kelompok: kelompok A (kontrol perlakuan) tidak diberi paparan kebisingan dan tidak diberi ekstrak biji anggur, kelompok B (kontrol negatif) tidak diberi paparan kebisingan dan diberi ekstrak biji anggur, kelompok $C, D, E$ (kelompok perlakuan) diberi paparan kebisingan dengan intensitas yaitu $65 \mathrm{~dB}, 85$ $d B, 105$ dB. Perlakuan diberi selama 33 hari. Hasil penelitian ini menunjukkan bahwa paparan kebisingan dengan intensitas berbeda $65 \mathrm{~dB}, 85 \mathrm{~dB}, 105 \mathrm{~dB}$ dapat menurunkan jumlah spermatozoa mencit jantan galur Swiss Webster yang diberikan ekstrak biji buah anggur. Hasil penelitian menggunakan uji One Way Anova dengan nilai p 0.001. Kesimpulan: Terdapat perbedaan antar kelompok kontrol dan kelompok perlakuan. Pemberian paparan kebisingan dengan nilai di atas ambang batas dapat menurunkan jumlah spermatozoa mencit jantan galur Swiss Webster yang diberikan ekstrak biji buah anggur

Kata kunci: Jumlah spermatozoa, Ekstrak biji buah anggur (Vitis vinifera L.), Kebisingan 


\section{INTRODUCTION}

Infertility is termed as an inability of a sexually active partner without contraception to get a pregnancy within one year ${ }^{1}$. In infertility cases, it is about $50 \%$ is due to "male factor" infertility with the occurrence of abnormalities in semen fluid examination. In the other report, infertility in 2013 there were $30-40 \%$ of infertility cases mostly occurred in male infertility problems ${ }^{2}$.

The parameter of male fertility assessed from the quality and quantity of spermatozoa consisting of the number, motility, and morphology of spermatozoa. Spermatozoa are cells produced by the function of sexual male reproduction. The process of spermatogenesis occurs in seminiferous tubules whose walls contain many germ cells and Sertoli cells. One cycle of spermatogenesis requires 64 days $^{2}$.

Male infertility is caused by impaired endocrine function due to the body's response to factors that cause a decrease in the quantity and quality of spermatozoa such as environmental pollution, stress, and free radicals (Consensus for Infertility Management, 2013). Psychological stress caused abnormality in the hypothalamus which leads to interfering with hormones, it resulted to inhibit Leydig cells to secrete testosterone ${ }^{3}$.

These psychological stress factors including temperature, medication, exposure to pollutants and radiation, alcohol, hormones, and noise exposure that exceeds threshold values ${ }^{3}$. In this study, we evaluate one of the psychological stress variables that most frequently exposed, the noise exposure that exceeds the threshold value.

Noise is a sound that causes disruption of workers in terms of work performance, physiological and psychological, hearing and communication, fatigue to stress $^{4}$. This study was conducted on male mice (Mus musculus L) because mice are animals that have an anatomical shape of spermatozoa that almost resembles human spermatozoa, mice are also able to adapt easily, and have a faster spermatogenesis cycle than male rats (Rattus norvegicus) which is around 32 day $^{5}$.
Several ways or materials can reduce the negative effects of noise exposure to decreased sperm quality, one of which is by providing antioxidants that are expected to reduce oxidative stress on sperm. Antioxidants compounds that have high effectiveness to reduce the negative effects of decreased sperm quality one of which is grape seeds ${ }^{5}$.

Grapes contain phenols that have benefits as inhibitors of tumor cell growth, anticancer, antiaging, anti-inflammatory, antimicrobial, reduce the risk of heart disease, and as an antioxidants that plays a role in stimulating androgen hormones (testosterone) in Leydig cells to roduce a normal process of spermatogenesis. Phenol in grape seeds has an antioxidants level 20 times greater than vitamin $\mathrm{E}$ and 50 times greater than vitamin $\mathrm{C}$. Besides OPC which has a protective effect of free radicals, lipid peroxidation and damage DNA is stronger than vitamins $\mathrm{C}, \mathrm{E}$, and beta-carotene ${ }^{6}$.

OPC consists of one of the resveratrol compounds which has an effect on the production of testosterone which can suppress cell proliferation, has an inhibitory effect on cell overgrowth, and has the potential to affect apoptosis and as a chemotherapy agent. In addition, the content of resveratrol has an effect in stimulating the production of testosterone in Leydig cells. So this reinforces research that grape seeds can suppress the negative affect of oxidative stress ${ }^{7}$.

The experimental study to test the effect of noise exposure on the number of spermatozoa of male mice (Mus musculus $L$ ) given grape seed extract (Vitis vinifera $L$ ) is needed to observe the direct effect of noise exposure on spermatozoa count.

\section{METHODS}

This study was conducted experimentally using a Post Test Control Group Design. A total of 30 male mice (Mus musculus $L$ ), age 8-12 weeks, weighing 20-30 grams and in good condition were divided into 5 groups. Each group consists of 6 mice. Group A (treatment control), group B (negative control), and groups $\mathrm{C}, \mathrm{D}, \mathrm{E}$ (treatment group). The treatment was given 
for 33 days according to the mice's sperm cycle and research from Munandar et al., $2013^{8}$.

All of the mice were adapted for a week by providing standard food and water before the treatment. After 7 days, the mice were treated according to the 5 groups. Group A (treatment control) was not given noise exposure and grape seed extract, group B (negative control) was not given noise exposure and was given grape seed extract, groups C, D, E (treatment group) were given noise exposure with sequential intensities of $65 \mathrm{~dB}, 85 \mathrm{~dB}, 105 \mathrm{~dB}$. The treatment was given for 33 days. The treatment was given every day for 8 hours. Started at 8 am -4 pm for 33 days. After 40 days, mice were terminated surgically to remove testicles, cauda epididymis, and distal parts of the vas deferens.

Pieces of cauda epididymis were inserted into a petri dish and dropped with 3 drops of $0,9 \% \mathrm{NaCl}$ solution. Spermatozoa suspension stirred homogeneously and counted with the hemocytometer Neubauer method. The result of the analysis of the sperm counts was expressed as Mean $\pm \mathrm{SD}$ and was evaluated by the One Way ANOVA test to determine the significant differences between groups with $\mathrm{p}<0,05$.

\section{RESULT}

The effect of noise exposure on the number of spermatozoa of male mice (Mus musculus) given grape seed extract (Vitis vinifera $L$ ) is shown.

Graph 1. Spermatozoa Count of Male Mice (Mus musculus L)

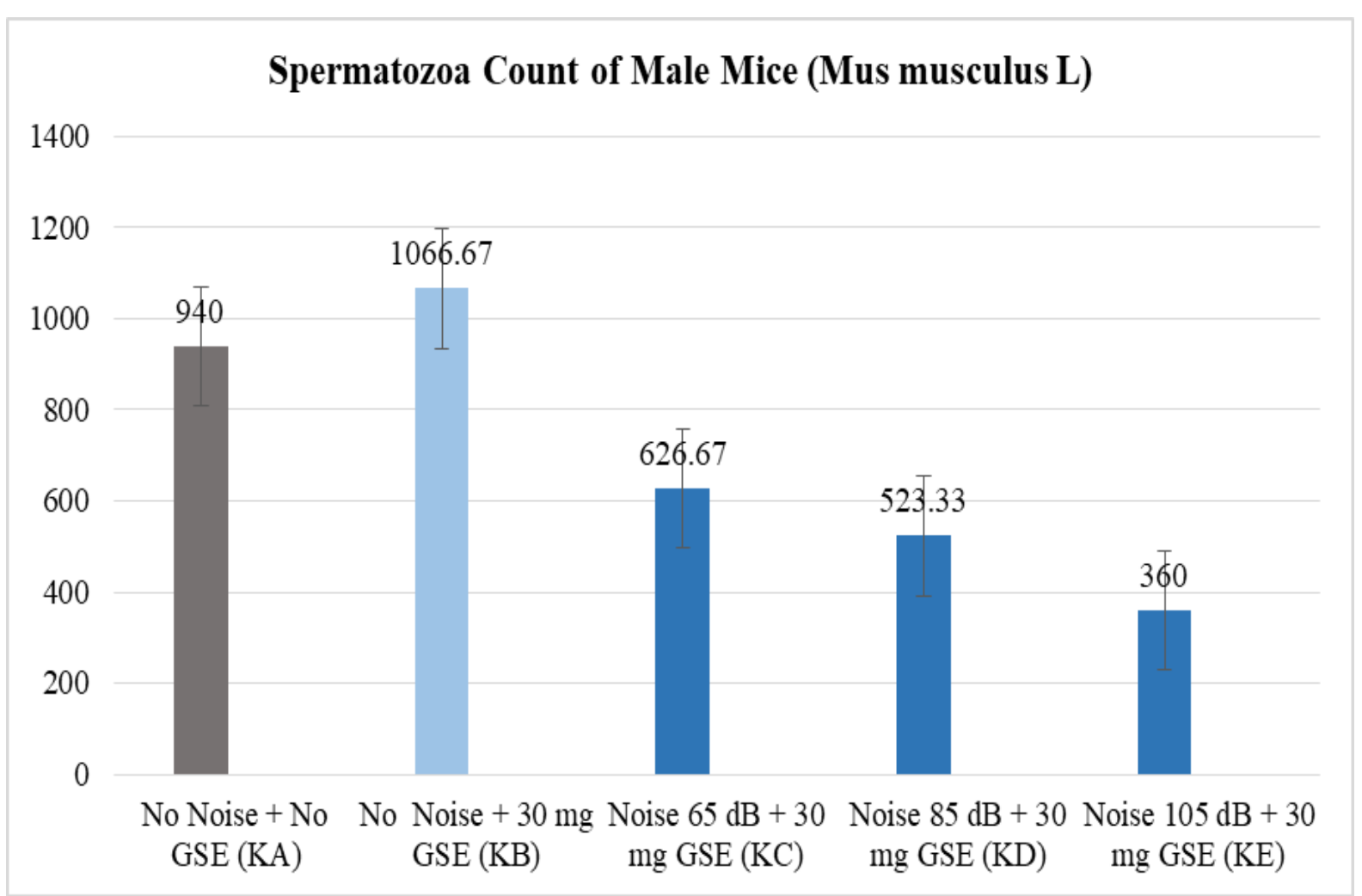


The results show that there is an increase in sperm count in the negative control group (KB) or the group without noise exposure given $30 \mathrm{mg}$ of grapefruit seed extract (GSE), with a higher number than the treatment control group (KA) or the group without noise exposure and administration $30 \mathrm{mg}$ GSE. In the treatment group, there was a significant decrease in each group with different noise intensities. The group with $65 \mathrm{~dB}(\mathrm{KC})$ noise exposure had the highest sperm count compared to the 2 other treatment groups. Followed by the group given $85 \mathrm{~dB}$ (KD) noise exposure had a higher sperm count than the group with $105 \mathrm{~dB}$ (KE) noise exposure (Graph. 1). Statistically, it is found that between treatment control, negative control, and treatment group with different noise exposure intensities is significantly different.

\section{DISCUSSION}

The man's fertility is related to the number and quality of sperm regulated by androgen hormones. Regulation of androgenic hormones in spermatogenesis consists of the initial process of spermatogenesis, proliferation, and maturation of Sertoli cells to the development of Germ cells, spermatogonia, meiosis, and spermiogenesis. The disruption of one of these mechanisms can result in a decrease in male fertility 9 .

Disturbances in hormones resulted in inhibition of processes in the hypothalamus and failure of Leydig cells to secrete the hormone testosterone. As a result, a decrease in testosterone cause disorders in the maturation process of spermatozoa in the epididymis, especially disorders in the process of glycolysis. The glycolysis process will form energy in the form of Adenosine Tri Phosphate (ATP). ATP acts as a source of energy \& to maintain the life of spermatozoa ${ }^{8}$.

Exposure to stress given continuously will increase the production of excess ROS, this can damage the genome of the spermatozoa mitochondria, so that energy production is disrupted and affect the spermatozoa motility and damage the sperm DNA so that normal spermatozoa in the testicular germ cells undergo apoptosis ${ }^{10}$. But if apoptosis occurs imperfectly, it can cause various losses. Apoptosis that occurs in germ cells will affect the decrease in the number of spermatozoa ${ }^{7}$.

The number of spermatozoa has decreased after noise exposure eventually leading to activation of the endocrine system in the pituitary-adrenal hypothalamus. As a result, there is a barrier to the release of $\mathrm{CRH}$ neurohormone which results in a decrease in the number of spermatogonia. This occurs when it decreases the secretion of LH, FSH, and testosterone. The lack of these three things can create obstacles to the direct proliferation of spermatogonium and ultimately interfere with the process of spermatogenesis. Spermatogenesis is a process that consists of proliferation, differentiation, and maturation of spermatogenic cells. So that if there is interference at one stage, it can affect the next process ${ }^{3}$.

Inhibited FSH secretion will cause disruption of Sertoli cell function, which disrupts the metabolic processes, resulting in the dead of spermatozoa. This is due to the fact that Sertoli cells have a function as a regulator, supporter, and protector for developing spermatozoa. The longer the noise exposure is given to male mice, the lower the average number of live spermatozoa. This shows that an increase in spermatozoa abnormalities due to noise exposure can cause infertility ${ }^{8}$.

The result also shows that in the absence of noise exposure, the grape seed extract increases the number of spermatozoa. The grape seed extract may reduce the negative effects of free radicals due to noisy stress is the grape seed extract. Grapes contain phenols that work as inhibitor of tumor cell growth, anti-cancer, antiaging, anti-inflammatory, anti-microbial, reduce the risk of heart disease and as an antioxidants that plays a role in stimulating androgen hormone (testosterone) in Leydig cells to reduce a normal process of spermatogenesis. Grape seeds themselves contain polyphenols, especially Oligomeric Proanthocyanidin Complex (OPC) based on previous research, which has 20 times greater than vitamin $\mathrm{E}$, and 50 times greater than 
vitamin C. Besides OPC which has a protective effect of free radicals, lipid peroxidation and damage DNA is stronger than vitamins $\mathrm{C}, \mathrm{E}$, and beta-carotene ${ }^{6}$.

OPC consists of one of the resveratrol compounds which has an effect on the production of testosterone which can suppress cell proliferation, has an inhibitory effect on cell overgrowth, and has the potential to affect apoptosis and as a chemotherapy agent. In addition, the content of resveratrol has an effect in stimulating the production of testosterone in Leydig cells. So this reinforces research that grape seeds can suppress the negative affect of oxidative stress ${ }^{11}$.

Even though, the assessment of spermatozoa is not enough to diagnose, nor is it in mice or mouse experimental animals. If the number of spermatozoa is normal but has an assessment of morphology and motility that is not good, can cause infertility in men. Conversely, if the number of spermatozoa is small but has a good morphological and motility assessment then a person can be said to be fertile even though it is not perfect ${ }^{12}$.

\section{CONCLUSION}

The noise exposure decreases the number of spermatozoa in mice (Mus musculus). The higher the noise level, the less the number of spermatozoa found. In addition, grape seed extract (Vitis vinifera L) increases the number of spermatozoa in the fully absent of noise exposure.

\section{REFERENCE}

1. World Health Organization [WHO]. National, Regional, and Global Trends in Infertility Prevalence Since 1990: A Systematic Analysis of 277 Health Surveys. PLoS Med [Internet]. 2012;9(12):1-12. Available from: https://journals.plos.org/ plosmedicine/article/file?id=10.1371/ journal.pmed.1001356\&type $=$ printable

2. Gede Wirya Kusuma Duarsa, Soebadi DM, Taher A, Purnomo BB, Rasyid $\mathrm{N}$, Noegroho BS, et al. GUIDELINES ON MALE INFERTILITY.
Vol. 2, Ikatan Ahli Urologi Indonesia. 2015. 8-9 p.

3. Erris, Harahap I. Pengaruh Kebisingan terhadap Kuantitas dan Kualitas Spermatozoa Tikus Putih (Rattus norvegicus) Jantan Dewasa. Media Litbangkes. 2015;24(3):1238.

4. Cahyani AA. Pengaruh Kebisingan Lingkungan Kerja terhadap Produktivitas Tenaga Kinerja Karyawan Dinas Kesehatan Kab. Sidoarjo. Muhammadiyah Univ Gresik Repos [Internet]. 2019;2(5):255. Available from: http://eprints.umg.ac.id/3160/

5. Konsensus PI. Konsensus Penanganan Infertilitas. Himpun Endokrinol Reproduksi dan Fertil Indones (HIFERI), Perhimpun Fertil Vitr Indones (PERFITRI), Ikat Ahli Urol Indones (IAUI), Perkumpulan Obstet dan Ginekol Indones Indones (IAUI), Perkumpulan Obstet dan Gin [Internet]. 2013; Available from: http://labcito.co.id/wp-content/ uploads/2015/ref/ref/

Konsensus_Infertilitas_Revisi_91.pdf

6. Perdana VP. Pengaruh Pemberian Ekstrak Biji Anggur Hijau (Vitis Vinifera) terhadap Gambaran Histopatologi Diberi Paparan Asap Rokok Tikus Putih (Rattus Norvegicus) Yang Dan Profil Protein Trachea Pada. Repos Univ Brawijaya [Internet]. 2017;(February 2019):1-13. Available from: http:// repository.ub.ac.id/127303/

7. Campbell NA. Campbell Biology. 11th ed. Jakarta: Penerbit Erlangga; 2015.

8. Munandar A, Nurcahyani N, Busman H. Pengaruh Kebisingan Terhadap Kualitas Spermatozoa Mencit (Mus musculus L.) [Internet]. Vol. 5, Seminar Nasional Sains \& Teknologi V Lembaga Penelitian Universitas Lampung. 2013. Available from: http:// repository.lppm.unila.ac.id/13469/1/25. Prosiding Saintek V Aris Munandar 2013.pdf 
9. Hasbi H, Gustina S. Regulasi Androgen dalam Spermatogenesis untuk Meningkatkan Fertilitas Ternak Jantan. Wartazoa [Internet]. 2018;28 (1):13-22. Available from: http;// dx.doi.org/10.14334/

wartazoa.v28il.1643

10. Haque O, Vitale JA, Agarwal A, Ples SS dusis. The Effect of Smoking on Male Infertility. Male Infertil [Internet]. 2014;19-30. Available from: https://link.springer.com/ chapter/10.1007\%2F978-1-4939-
1040-3 2

11. Qotrunnada S. Spermatogenesis dan Spermatozoa. J Univ Diponegoro, [Internet]. 2018;6. Available from: https://

www.eprints.undip.ac.id/62448/3/

Sho-

fia_Qotrunnada_22010114120072_B $\mathrm{AB}_{-}$2.pdf

12. Jung A, Schuppe H. Infulence of Genital Heat Stress on Semen Quality in Humans. Andrologia, 2007;39:203-15. 